\title{
Discussion: Preconference tour report: Garstang and Catterall flood alleviation scheme
}

\author{
Andrew Pepper BSc (Hons), CEng, MICE, FCIWEM
}

Director, ATPEC Ltd, Surrey, UK

\section{Contribution by A. Pepper}

This reader would like to put forward the following comments on the paper by Claydon (2017).

I was interested in the penultimate paragraph of the report, which stated that when the Environment Agency operated the above flood storage reservoirs it had to pay compensation for damage and loss of crops after each flood event. Although that arrangement may be unique to these two reservoirs in that area of the Environment Agency it is not unique throughout the country.

The reason that this arrangement is rare is that it has a number of disadvantages when compared to the alternative, a commuted lump sum, payable at the time of construction, for all crop losses or surface damages in perpetuity. The disadvantages of the per-event payments include

- The compensation must be paid from revenue, as the capital scheme will have been closed.

- The sum cannot be budgeted for in advance, as neither the timing nor amount can be known, especially if the occupier decides to grow high value but highly susceptible crops in the reservoir basin.

- Significant fees may be incurred by both the Environment Agency's and the occupiers' land agents in agreeing an appropriate figure for comparison - all fees being paid for by the Environment Agency.

- The difficulty of separating damage due to inundation from damage that would have occurred anyway due to the weather conditions that typically cause a flood storage reservoir to operate.

Until recently, I was the supervising engineer for an Environment Agency flood storage reservoir at Radlett, Hertfordshire, where this arrangement of compensation - that is payment per event, was agreed when the reservoir was constructed in 2003, namely

Each time any part of the flood envelope land is flooded then the Environment Agency shall pay full compensation to the qualifying occupier of the affected part of the flood envelope land for any crop loss or surface damage arising from each separate flood event.

The amount of the compensation payable is to be determined by agreement between the agency and the relevant qualifying occupier or their respective surveyors or agents. If compensation cannot be agreed on within 3 months of the flood event giving rise to the entitlement for compensation, then the question of the amount of compensation may be referred by either party to arbitration under the terms of the Arbitration Act 1996 or unless before such reference is made one party requires the dispute to be referred instead to an independent expert.

The reasonable and proper costs of each qualifying occupiers surveyors should also be paid by the Environment Agency.

At Radlett, the maximum area potentially inundated (i.e. to spillway level) in the one in 75 year flood event is about 14 ha, but to date (October 2017) the greatest storage volumes have been from two events in February 2014, $6 \mathrm{~d}$ apart, with the larger event storing just under $25 \%$ of the available volume, and inundating $6 \mathrm{ha}$. In these two events flood storage occurred for $6 \frac{1}{2}$ and $9 \frac{1}{2} \mathrm{~h}$, respectively.

No claim was received, and indeed due to the time of year, the short durations and the very wet weather at the time I consider it very doubtful that any claim would have been successful.

\section{REFERENCE}

Claydon JR (2017) Preconference tour report: Garstang and

Catterall flood alleviation scheme. Dams and Reservoirs 27(2):

50-51, https://doi.org/10.1680/jdare.17.00005. 